Article

NADEEM, M. ${ }^{1}$

TANVEER, A. ${ }^{1 *}$

KHALIQ, A. ${ }^{1}$

MURTAZA, G. ${ }^{2}$

\section{SuPPRESSION OF MAIZE (Zea mays) SEEDLING GROWTH BY INVASIVe AlligatoRWEed (Alternanthera philoxeroides) RESIDUES}

\author{
Supressão do Crescimento de Plântulas de Milho por Resíduos de Erva-de- \\ Jacaré (Alternanthera philoxeroides)
}

\begin{abstract}
To investigate the allelopathic influence of soil incorporated plant residues of alligatorweed on emergence and seedling growth of maize (Zea mays), an experiment was conducted under laboratory conditions in the 2014-15 period. The effect of soil amended with whole plant residues of alligatorweed at different concentrations (1, 2, 3, 4 and $5 \%$ on $\mathrm{w} / \mathrm{w}$ basis) was compared with residue free soil (control). Emergence traits, such as emergence percentage, time to 50\% emergence, mean emergence time and emergence index were negatively influenced by weed residue incorporation as compared with weed residue free soil. Alligatorweed residues also exerted a pronounced negative influence on root and shoot lengths, root and shoot dry weights and seedling vigor index of the maize crop. The results revealed that the inhibitory effect was directly proportional to the increasing concentrations $(1,2,3,4$ and $5 \%)$ of the weed residues as compared to control treatment. It was observed that soil infested with $4 \%$ and 5\% residues of alligatorweed caused a maximum reduction in emergence ( $76-87 \%$ ), root and shoot lengths $(58-73 \%$ and $42-$ $61 \%$ ), root and shoot dry weights ( $49-58 \%$ and $40-48 \%$ ) and seedling vigor index (87$95 \%$ ) of the maize crop. Chloro-genic acid, ferulic acid, 4-hydroxy-3-methoxybenzoic acid, trans-4-hydroxy 3-methoxy cinnamic acid, gallic acid, $p$-coumaric acid, querceitin and syringic acid were identified as water soluble phenolics in alligatorweed residue soil saturated solution. This study indicates that the allelopathic potential of alligatorweed may play an important role in suppressing maize seedling growth.
\end{abstract}

Keywords: invasive weed, allelopathy, emergence, maize, weed residues, seedling growth.

RESUMO - A fim de investigar a influência alelopática de resíduos vegetais de erva-de-jacaré incorporados no solo na emergência e no crescimento de plântulas de milho (Zea mays), foi conduzido um experimento em condições de laboratório no período 2014-15. O efeito do solo corrigido com resíduos vegetais inteiros de erva-de-jacaré em diferentes concentrações (1, 2, 3, 4 e 5\% em uma razão p/p) foi comparado com o do solo livre de resíduos (controle). As características de emergência, como porcentagem de emergência, tempo de emergência de $50 \%$ das plântulas, tempo médio de emergência e índice de emergência, foram influenciadas negativamente pela incorporação de resíduos de plantas daninhas, em comparação com o solo livre destas plantas. Os resíduos de erva-de-jacaré também exerceram influência negativa acentuada sobre os comprimentos da raiz e da parte aérea, os pesos secos da raiz e da parte aérea e o índice de vigor das plântulas da cultura de milho. Os resultados revelaram que o efeito inibitório foi diretamente proporcional ao aumento das concentrações (1, 2, 3, 4 e 5\%) dos residuos de plantas daninhas,

Planta Daninha 2017; v35:e017165295

1 Department of Agronomy, University of Agriculture, Faisalabad, 38040 (Pakistan); ${ }^{2}$ Institute of Soil and Environmental Sciences, University of Agriculture, Faisalabad, 38040 (Pakistan). 
em comparação com o tratamento controle. Observou-se que o solo infestado com 4\% e 5\% de resíduos de erva-de-jacaré causou redução máxima na emergência (76-87\%), no comprimento da raiz e da parte aérea (58-73\% e 42-61\%), no peso seco da raiz e da parte aérea (49-58\% e 40-48\%) e no índice de vigor de plântulas (87-95\%) da cultura de milho. Ácido clorogênico, ácido ferúlico, ácido 4-hidroxi-3metoxibenzoico, ácido-4-hidroxi-3-metoxi-trans-cinâmico, ácido gálico, ácido p-cumárico e ácido siríngico foram identificados como fenólicos solúveis em água. O presente estudo indica que o potencial alelopático da erva-de-jacaré pode desempenhar papel importante na supressão do crescimento de plântulas de milho.

Palavras-chave: plantas invasoras, alelopatia, emergência, milho, resíduos de plantas daninhas, crescimento de plântulas.

\section{INTRODUCTION}

Invasive plants species are responsible for disrupting the stability of natural ecosystems and native biodiversity and for causing major economic losses in agriculture, forestry, livestock husbandry, and many other industries worldwide (Pimentel et al., 2005; Holmes et al., 2009). These plants can grow, spread and dominate in a new range to cause detrimental effects on preexisting native ecosystems (Mack et al., 2000). There are several characteristics which explain the success of invasive species over native species, e.g., growth rate or resource use (Maron et al., 2004), rapid evolution in the introduced range, phenotypic plasticity, high seed production and successful dispersal mechanisms, reproduction, and longer photosynthetic periods (Ehrenfeld et al., 2001; Bossdorf et al., 2005). Recently, it has been reported that allelopathy plays a key role in weed invasions, particularly when invaders release compounds that reduce germination, growth and/or reproduction of native plants (Hierro and Callaway, 2003; Inderjit et al., 2008). The mode of entry of allelopathic substances into the environment plays an important role in the expression of their phytotoxic properties (Zimdahl, 2007).

Several reports have documented the deleterious effect of decaying and decomposing weed residues on germination, growth and yield of subsequent crops in the field (Khaliq et al., 2011). The mechanisms for the allelochemicals to be released from plants into the environment have a significant role in affecting other plants in the vicinity (Safdar et al., 2014). These allelochemicals may be washed directly from the weed residues or may become more toxic after being transformed by microbial activity during decomposition (Kumar et al., 2006).

Maize (Zea mays) is the third most important cereal crop after wheat and rice on the basis of grain production in the world. Among various factors considered for yield reduction in maize, weeds have supreme importance as they decline maize yield up to $90 \%$ depending on degree of weed infestation (Chikoye and Ekeleme, 2003; Dalley et al., 2006). The main harmful weeds causing significant yield reduction in maize are Amaranthus viridis (wild amaranth), Cyperus rotundus (nut grass), Cynodon dactylon (bermuda grass), Echinochloa colona (jungle rice) and Trianthema portulacastrum (horse purslane) (BCS, 2015).

In addition to these weeds, alligator weed is now emerging as an invasive weed in maize crops of Pakistan which seems to be more proliferating and problematic than conventional weeds. It is native to southern South America (Argentina, Paraguay, Uruguay and Brazil). It is a problematic weed of 30 countries in the world including USA, Puerto Rico, New Zealand, Burma, China, Thailand, Indonesia and Australia, where it has been considered as an invasive alien weed. It is listed among the 20 weeds of national significance in Australia (Gunasekera and Bonilla, 2001).

Alligator weed can invade agricultural crops, leading to crop failure. It is considered as an invasive and troublesome weed in rice, maize, cotton, soybean, vegetables and fruit trees in China (Lu et al., 2002; Ye et al., 2003). Alligator weed has been proliferating in different field crops in that country because the local ecological conditions favor its growth. The literature shows that no information is available about the allelopathic effects of alligator weed residues on emergence and seedling growth of maize. It is hypothesized that alligator weed residues may hamper the emergence and seedling growth of maize plants by releasing water-soluble phenolics. 
Therefore, the present study was planned with the objective to assess the allelopathicity of alligator weed against the emergence and early seedling growth of maize.

\section{MATERIALS AND METHODS}

\section{Collection and mechanical processing of plant material}

Field grown plants of alligator weed were uprooted at maturity from the Agronomic research area, University of Agriculture, Faisalabad, Pakistan, in August and repeated in September 2014. These weed plants were washed in distilled water for removal of dust and soil particles and then dried at room temperature $\left(30^{\circ} \mathrm{C} \pm 4\right)$ for seven days. The well-dried plants were chopped into about $5 \mathrm{~cm}$ pieces with a pair of scissors. In order to study the effect of alligator weed residues on emergence and early seedling growth of maize, the soil was collected from a profile of 0 to $25 \mathrm{~cm}$ on a weed free site. The soil was air dried, sieved and stored in plastic bags at room temperature. The soil was sandy loam.

\section{Seedling emergence and growth bioassay in soil amended with alligator weed residues}

Under natural field conditions, residues of alligatorweed fall on the soil surface and get mixed with the soil with subsequent tillage practices. In order to simulate these natural conditions, 3, 6, 9, 12 and $15 \mathrm{~g}$ of alligator weed residues were added and mixed with $300 \mathrm{~g}$ of soil already collected so as to get $1,2,3,4$, and $5 \%(\mathrm{w} / \mathrm{w})$ concentrations, respectively. The pots measured $5 \mathrm{~cm} \times 12.5 \mathrm{~cm}$ and were filled with soil already mixed with alligator weed residues $(0,1,2,3,4$ and $5 \%$ on $\mathrm{w} / \mathrm{w}$ basis). Then, $100 \mathrm{~mL}$ of distilled water was added to each pot and pots were kept at room temperature for 15 days. As a control, $300 \mathrm{~g}$ of unmodified soil was soaked in $100 \mathrm{~mL}$ of water for 15 days. Ten seeds of maize hybrid "30R50" were sown in each pot. Pots were placed on a laboratory bench. Each pot was watered with $20 \mathrm{~mL}$ of water daily. The experiment was laid out in a completely randomized design with four replications. A maximum temperature of $32{ }^{\circ} \mathrm{C}$ and a minimum temperature of $28{ }^{\circ} \mathrm{C}$ were recorded throughout the course of the experiment.

Fifteen-day old seedlings were uprooted and washed with water and their shoot and root lengths and dry weights were recorded after drying in an electrical oven at $70{ }^{\circ} \mathrm{C}$ for 48 hours.

\section{Data collection and statistical analysis}

The number of seeds emerged was counted daily up to fifteen days. Seedlings were considered emerged when the coleoptile was first visible at the soil surface. Emergence was observed daily in accordance with the methods of the Association of Official Seed Analysis (AOSA, 1990). Emergence count data were used to calculate various seed emergence and vigor parameters as detailed below:

Emergence percentage (EP) was calculated by the following formula:

$$
\mathrm{EP}=\left[\mathrm{N}_{\mathrm{T}} \times 100\right] / \mathrm{N}
$$

where $\mathrm{N}_{\mathrm{T}}$ : the proportion of emerging seeds in each treatment for the final measurement, and $\mathrm{N}$ : number of seeds used in the bioassay.

Mean Emergence Time (MET) was calculated as per the equation of Ellis and Roberts (1981).

$$
\mathrm{MET}=\Sigma \mathrm{Dn} / \Sigma \mathrm{n}
$$

where $\mathrm{n}$ is the number of seeds that had emerged on day $\mathrm{D}$ and $\mathrm{D}$ is the number of days counted from the beginning of emergence.

Time taken to $50 \%$ emergence $\left(\mathrm{E}_{50}\right)$ was calculated by using the formula given by Coolbear et al. (1984) as modified by Farooq et al. (2005).

$$
\mathrm{T}_{50}=\mathrm{ti}+\{(\mathrm{N} / 2)-\mathrm{ni}\}\left(\mathrm{tj}-\mathrm{t}_{\mathrm{i}}\right) / \mathrm{nj}-\mathrm{ni}
$$


where $N$ is the final number of germinated seeds while $n j$ and $n i$ are the cumulative numbers of seeds germinated by adjacent counts at times $t j$ and $t i$, respectively, where $n i<N / 2<n j$.

Emergence index (EI) was calculated as given by following the formula described by Scott et al. (1984):

$$
\mathrm{EI}=\mathrm{N} 1 / \mathrm{D} 1+\ldots \ldots \ldots \ldots \ldots \ldots+\mathrm{NL} / \mathrm{DL}
$$

where N1: number of seeds emerged on $1^{\text {st }}$ count, D1: days to $1^{\text {st }}$ count, NL: number of seeds emerged on the last count, and DL: days to last count. (1977):

Seedling vigor index (SVI) was calculated by the following formula as described by Orchard

$$
\text { SVI }=\text { seedling length }(\mathrm{cm}) \times \text { emergence percentage }
$$

Emergence energy (EE) was recorded on the 4th day after planting. It is the percentage of germinating seeds 4 days after planting relative to the total number of seeds tested (Ruan et al., 2002).

Soil aqueous extracts were tested for their biochemical characteristics. Those were prepared by soaking $10 \mathrm{~g}$ soil in $100 \mathrm{~mL}$ distilled water for 24 hours. The soil extracts were then filtered by the use of micro-syringe filters. Total soluble phenolics were determined as described by Randhir and Shetty (2005) and were expressed as gallic acid equivalents. For identification and quantification of their suspected phytotoxins, aqueous extracts were chemically analyzed (Table 1) on a Shimadzu HPLC system (Model SCL-10A, Tokyo, Japan). The peaks were detected by a UV detector. Standards of suspected phytotoxins (Aldrich, St Louis, USA) were run similarly for their identification and quantification.

Table 1 - Phytotoxic composition of soil amended with alligatorweed residues (mg L-1)

\begin{tabular}{|c|c|c|c|c|c|c|c|c|}
\hline $\begin{array}{c}\text { Residue } \\
\text { conc. } \\
(\%)\end{array}$ & $\begin{array}{c}\text { Gallic } \\
\text { acid }\end{array}$ & $\begin{array}{c}\text { 4-hydroxy-3- } \\
\text { methoxyben- } \\
\text { zoic acid }\end{array}$ & $\begin{array}{c}p \text {-coumaric } \\
\text { acid }\end{array}$ & $\begin{array}{c}\text { Chlorogenic } \\
\text { acid }\end{array}$ & Quercetin & $\begin{array}{c}\text { trans-4- } \\
\text { hydroxy 3- } \\
\text { methoxy } \\
\text { cinnamic acid }\end{array}$ & Ferulic acid & Syringic acid \\
\hline 0 & 0 & 20.84 & 1.33 & 0 & 0.47 & 8.36 & 30.27 & 0 \\
\hline 1 & 0 & 25.72 & 1.44 & 8.73 & 0.41 & 14.25 & 29.88 & 0 \\
\hline 2 & 0 & 30.54 & 1.67 & 9.62 & 0.16 & 29.23 & 20.32 & 0 \\
\hline 3 & 0.65 & 28.42 & 1.83 & 10.72 & 0.12 & 33.27 & 17.78 & 1.23 \\
\hline 4 & 0.82 & 33.26 & 2.79 & 13.24 & 0.23 & 44.42 & 18.36 & 1.38 \\
\hline 5 & 0.9 & 34.56 & 2.96 & 14.31 & 0.3 & 39.21 & 15.58 & 0.82 \\
\hline
\end{tabular}

Concentration of each isolated compound was determined by the following equation:

$$
\text { Conc. }(\text { ppm })=\frac{\text { Area of the sample }}{\text { Area of the standard }} \times \text { Concentration of the standard } \times \text { Dilution factor }
$$

The average data collected in study were analyzed statistically using Fisher's analysis of variance techniques (Steel et al., 1997) using the computer software Statistix 8.1. Tukey's Honestly Significant Difference (HSD) test was applied at $5 \%$ probability level to test the significance of treatment means. The experiment was repeated twice. The results have been presented and described for the first experiment conducted because the repeated experiment showed similar results.

\section{RESULTS AND DISCUSSION}

Data on various emergence and seedling growth parameters of maize as influenced by the residue amended soils of alligator weed are shown in Figures 1 and 2. The results revealed that 

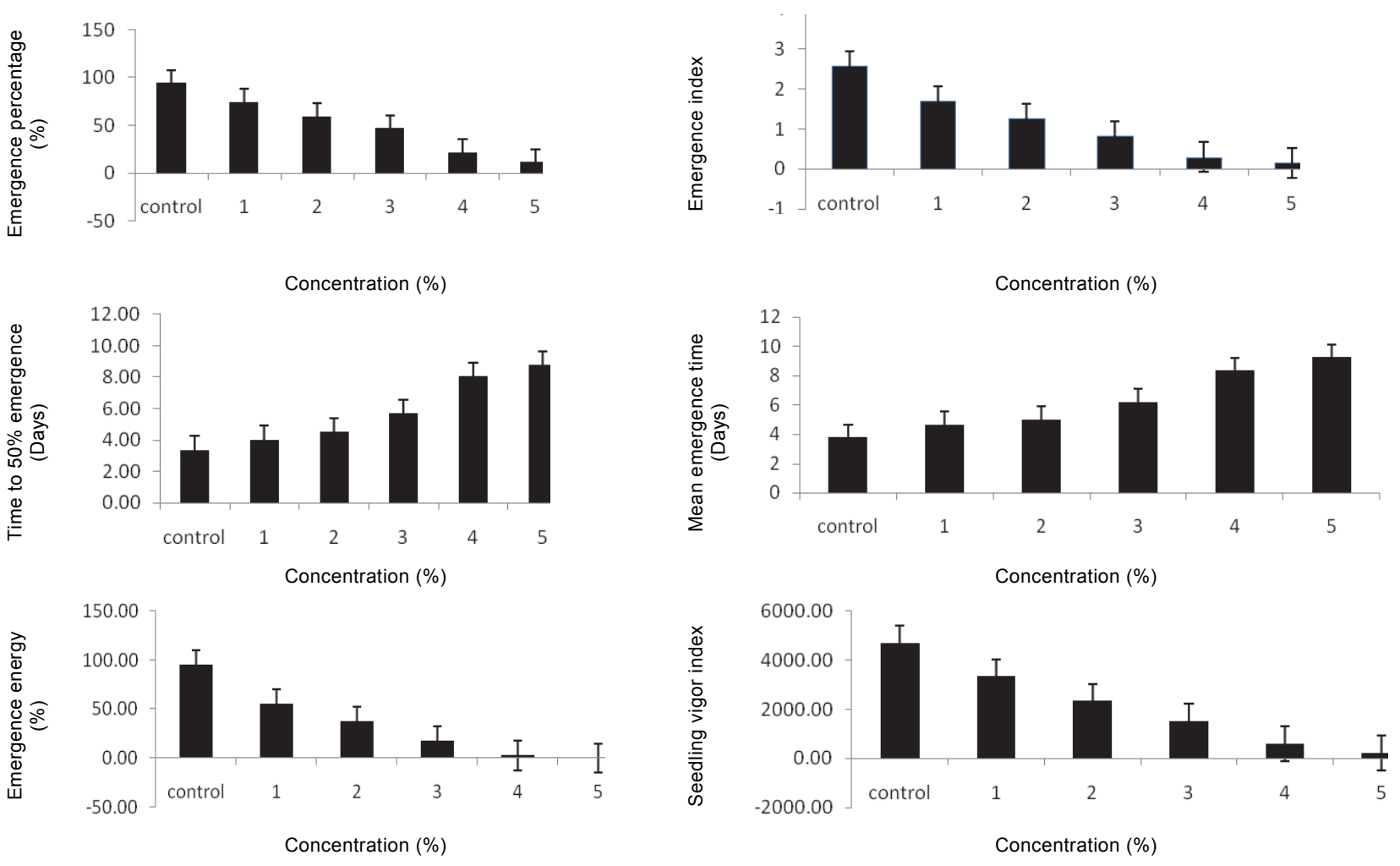

Bars indicate standard error of means.

Figure 1 - Means of emergence parameters of maize as influenced by soil amended with alligator weed residues.

alligator weed residues affected all the emergence traits of the maize crop. The residues of alligator weed at their $5 \%$ concentration caused maximum inhibition in emergence percentage, emergence energy (EE) and emergence index (EI) of maize.

In the soil amended with alligator weed residues, emergence percentage of maize was reduced to $21,37,50,76$ and $87 \%$ at their $1,2,3,4$ and $5 \%$ concentrations, respectively, when compared with the control.

Emergence index (EI) is a measure of both percentage and speed of germination. Early-grown seeds have more EI than late-grown seeds. It means maximum weightage is given to the seeds emerging on the first day. Figure 1 showed that alligator weed residues reduced EI with increasing residues concentration as compared to the unmodified soil (control). Minimum emergence index (0.14) was recorded with seeds sown in soil amended with alligator weed residue with 5\% concentration.

The lowest $\mathrm{EE}$ (2.5 and 0 ) was found by the treatments containing soils with 4 and $5 \%$ concentrated alligator weed residues (Figure 1).

Data shown in Figure 1 revealed that alligator weed residues of all concentrations significantly delayed time to $50 \%$ emergence and mean emergence time as compared with the control.

Seedling vigor index (SVI) values were significantly reduced in response to alligator weed residues (Figure 1). The minimum seedling vigor index (220) was recorded where alligator weed residues were $5 \%$.

The inhibition in all the seed emergence traits of maize by increasing the concentration of alligator weed residues in soil was probably due to the phytotoxic influence of gallic acid, 4-hydroxt-3methoxybenzoic acid, $p$-coumaric acid, chlorogenic acid, trans-4-hydroxy-3-methoxy cinnamic acid and syringic acid because these allelochemicals showed a consistent increase in soil by increasing alligator weed residue concentration (Table 1). These results are supported by those of Zuo et al. (2012), who reported that the species Alternanthera grown under aquatic 
conditions have strong allelopathic potential and produce more allelopathic substances. Similar findings were also reported by Zhang et al. (2009) and Dhole et al. (2011). They revealed that A. philoxeroides, A. sessilis and E. crus-galli suppressed the growth of sorghum and ryegrass by both competition and release of secondary metabolites in the ecosystem.

Data on various maize seedling growth parameters as affected by the different concentrations of alligator weed residues are shown in Figure 2, which revealed that alligator weed residues have significant inhibitory effects on seedling root and shoot lengths, and their dry weight at all concentrations as values of these parameters were gradually reduced in response to increasing concentration of residues in soil as compared with the control soil. The lowest values for shoot length $(12.88 \mathrm{~cm})$ and dry weight $(95.00 \mathrm{mg})$, root length $(4.63 \mathrm{~cm})$ and dry weight $(38.75 \mathrm{mg})$, seedling length $(17.50 \mathrm{~cm})$ and dry weight of maize seedlings $(133.75 \mathrm{mg})$ were recorded with alligator weed residues at $5 \%$ concentration.

The deleterious phyto-inhibitory influence on seedling growth of maize in response to increasing concentration of alligator weed residues seems to be due to an increase in the concentrations of gallic acid, 4-hydroxt-3-methoxybenzoic acid, p-coumaric acid, chlorogenic acid, trans-4-hydroxy-3-methoxy cinnamic acid and syringic acid in soil (Table 1). Alligator weed residues released growth-suppressing substances into the soil environment, which accumulate in such bioactive concentrations that they adversely influence the growth of maize plants. Similar results were recorded by Liu-Qing et al. (2007), who reported that alligator weed inhibited the root growth of lettuce (Lactuca sativa) and barnyard grass (E. crus-galli) by releasing growthsuppressing substances. Abbas et al. (2014) also published similar findings that aquatic weeds (A. philoxeroides, A. sessilis, Conyza stricta, Polygonum barbatum and E. crus galli) released allelochemicals which affected the growth of wheat in a rice-wheat cropping system.

Channappagoudar et al. (2005) recorded that phenolic compounds are the main allelochemicals which cause inhibition in seed emergence and early seedling growth of plants. A further analysis showed that with increasing concentration of residues, there is a higher rate of release of phenolics. The range of total phenolic concentration was 277-565 ug g-1 with alligator
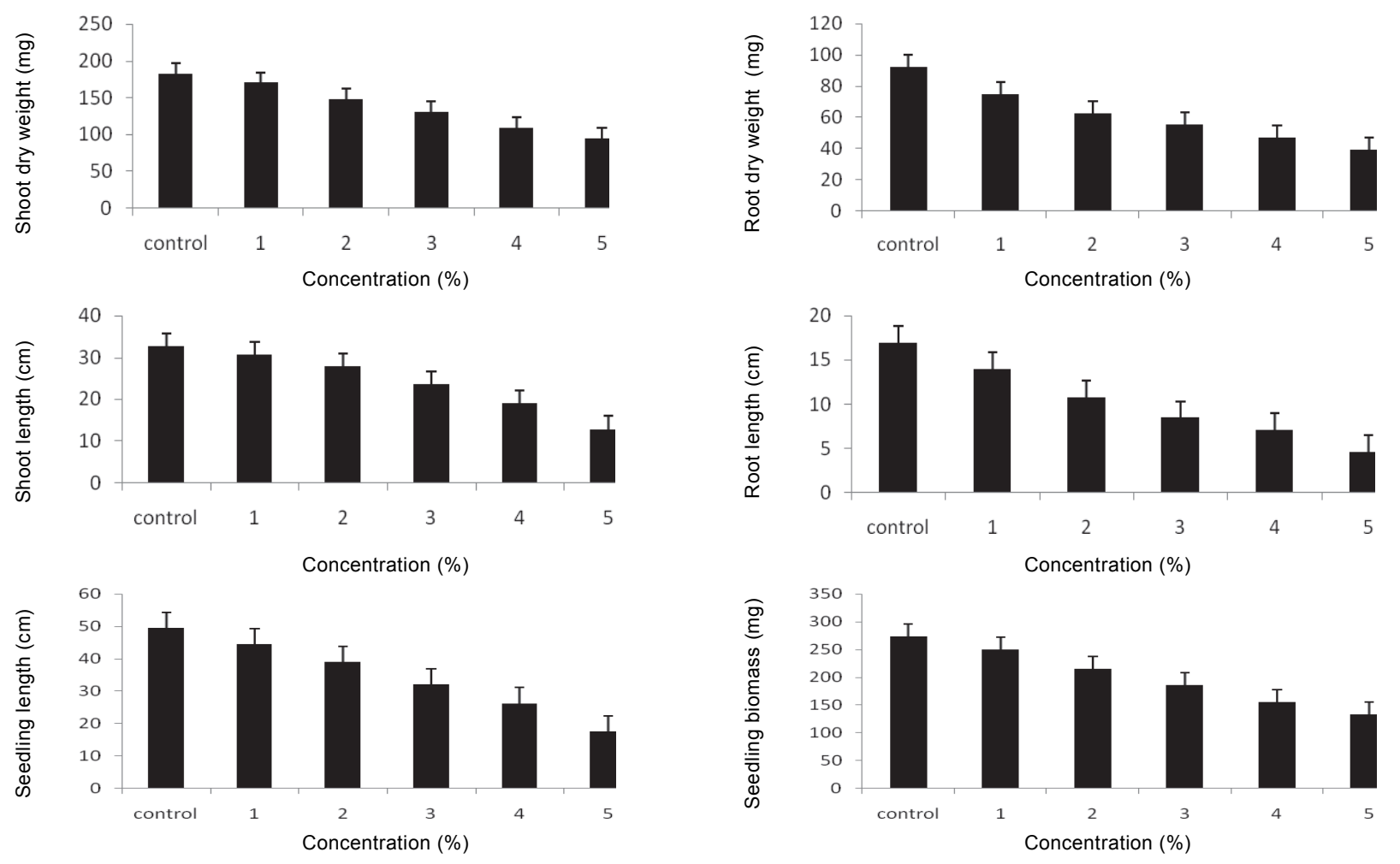

Bars indicate standard error of means.

Figure 2 - Means of seedling growth of maize as influenced by soil amended with alligator weed residues. 
weed residues range of $0-5 \%$ on a $\mathrm{w} / \mathrm{w}$ basis (Table 2). This study is in agreement with earlier studies reported by Abbas et al. (2015). They concluded that alligator weed residues have

Table 2 - Total amount $\left(\mathrm{ug} \mathrm{g}^{-1}\right)$ of water soluble phenolics in soil amended with alligator weed residues

\begin{tabular}{|c|c|}
\hline Concentration (\%) & Total phenolic concentrations \\
\hline 0 (control) & 277 \\
\hline 1 & 307 \\
\hline 2 & 311 \\
\hline 3 & 362 \\
\hline 4 & 454 \\
\hline 5 & 565 \\
\hline
\end{tabular}
water soluble phenolics in their tissues which influence the sustainability of rice ecosystems and rice-wheat cropping systems. On the basis of these results, we can conclude that alligator weed residues have phyto-toxic substances released after decomposition into the soil which can inhibit the emergence and seedling growth of maize crops. However, more detailed research is needed so that their allelopathic based crop growth inhibition can be studied in different crops.

\section{ACKNOWLEDGEMENTS}

This study is a part of the main author's thesis research work for a Ph.D. degree at the Department of Agronomy, University of Agriculture, Faisalabad, Pakistan. The financial support of the Higher Education Commission, Government of Pakistan under indigenous Ph.D. (5000 fellowships) program is highly acknowledged. The authors of this study are also warmly thankful to and acknowledge the Agriculture Department, Government of Punjab, Pakistan, for the nomination to complete Ph.D. studies on a study leave basis at the University of Agriculture, Faisalabad, Pakistan.

\section{REFERENCES}

Abbas T. et al. A. Comparative influence of water soluble phenolics of warm climate aquatic weeds on weeds species composition and rice-wheat cropping system. Sci Agric. 2015;10:145-50.

Abbas T. et al. Allelopathic effects of aquatic weeds on germination and seedling growth of wheat. Herbologia. 2014;14:22-36.

Association of Official Seed Analysis - AOSA. Rules for testing seeds. J Seed Technol. 1990;12:1-112.

BCS. Bayer Crop Science. 2015. [accessed on: 2015 Oct 30] Available at: http://www.bayercropscience.com.pk/BCSWeb/www/ BCS_PK_Internet.nsf/id/EN_Maize?open\&ccm=100010

Bossdorf O. et al. Phenotypic and genetic differentiation between native and introduced plant populations. Oecologia. 2005;144:1-11.

Channappagoudar B.B. et al. Allelopathic effect of aqueous extracts of weed species on germination and seedling growth of some crops. Karnataka J Agric Sci. 2005;18:916-20.

Chikoye D., Ekeleme F. Cover crops forcogongrass management and effects on subsequent yield. Weed Sci. 2003;51:792-7.

Coolbear P. et al. The effect of low temperature pre-sowing treatment on the germination performance and membrane integrity of artificially aged tomato seeds. J Exper Bot. 1984;35:1609-17.

Dalley C.D. et al. Effect of weed removal timing and spacing on soil moisture in corn (Zea mays L.). Weed Technol. 2006;20:399-409.

Dhole J.A. et al. Allelopathic effect of aqueous extract of five selected weed species on seed mycoflora, seed germination and seedling growth of Sorghum vulgare Pers. (Jawar). Res J Pharm Biol Chem Sci. 2011;2:142-8.

Ehrenfeld J.G. et al. Changes in soil functions following invasions of exotic understory plants in deciduous forests. Ecol Appl. 2001;11:1287-300.

Ellis R.A., Roberts E.H. The quantification of aging and survival in orthodox seeds. Seed Sci Technol. 1981;9:373-409. 
Farooq M. et al. Thermal hardening: a new seed vigor enhancement tool in rice. J Integr Plant Biol. 2005;47:187-93.

Gunasekera L., Bonilla J. Alligatorweed : tasty vegetable in Australian backyards? J Aquat Plant Manag. 2001;39:17-20.

Hierro J.L., Callaway R.M. Allelopathy and exotic plant invasion. Plant Soil. 2003;256:29-39.

Holmes T.P. et al. Economic impacts of invasive species in forests: Past, present, and future. Ann New York Acad Sci. 2009;1162:18-38.

Inderjit et al. Allelopathy and plant invasions: Traditional, congeneric and bio-geographical approaches. Biol Inv. 2008;10:875-90.

Khaliq A. et al. Allelopathic activity of crop residue incorporation alone or mixed against rice and its associated grass weed jungle rice (Echinochloa colona [L.] Link). Chilean J Agric Res. 2011;71:418-23.

Kumar M. et al. Phytotoxic effects of agroforestry tree crops on germination and radical growth of some food crops of Mizoram. Lyonia. 2006;11:83-9.

Liu-Qing Y.U. et al. Comparison of allelopathy potential between an exotic invasive weed Alternanthera philoxeroides and a local weed A. sessilis. Chinean J Rice Sci. 2007;21:84-9.

Lu Y.L. et al. Research status quo on alligator weed in China. J Jianshu Agric. 2002;4:46-8.

Mack R.N. et al. Biotic invasions: causes, epidemiology, global consequences and control. Ecol Appl. 2000;10:689-710.

Maron J.L. et al. Rapid evolution of an invasive plant Ecol Monogr. 2004;74:261-80.

Orchard T. Estimating the parameters of plant seedling emergence. Seed Sci Technol. 1977;5:61-9.

Pimentel D. et al. Update on the environmental and economic costs associated with alien invasive species in the United States. Ecol Econ. 2005;52:273-88.

Randhir R., Shetty K. Developmental stimulation of total phenolics and related antioxidant activity in light and dark germinated maize by natural elicitors. Proc Biochem. 2005;40:1721-32.

Ruan S. et al. The influence of priming on germination of rice (Oryza sativa L.) seeds and seedling emergence and performance in flooded soils. Seed Sci Technol. 2002;30:61-7.

Safdar M.E. et al. Allelopathic action of parthenium and its rhizospheric soil on maize as ifluenced by growing conditions. Planta Daninha. 2014;32:243-53.

Scott S.J. et al. Review of data analysis methods for seed germination. Crop Sci. 1984;24:1192-9.

Steel R.G.D. et al. Principles and procedures of statistics: a biometrical approach. $3^{\text {rd }}$. ed. New York: McGraw-Hill Book, 1997. p.172-7.

Ye W.H. et al. Genetic uniformity of Alternanthera philoxeroides in south China. Weed Res. 2003;43:297-302.

hang Z. et al. Allelopathic effects of tissue extract from alligatorweed on seed and seedling of ryegrass. Acta Bot BorealiOccidentalia Sin. 2009;29:148-53.

Zimdahl R.L. Fundamentals of weed science. $3^{\text {rd }}$. ed. London: Academic Press, 2007. 228p.

Zuo S. et al. Differences in ecological and allelopathic traits among Alternanthera philoxeroides populations. Weed Biol Manag. 2012;12:123-30. 